\title{
Improving the Fragile States' Budget Transparency: Lessons from Afghanistan
}

\section{Nematullah Bizhan}
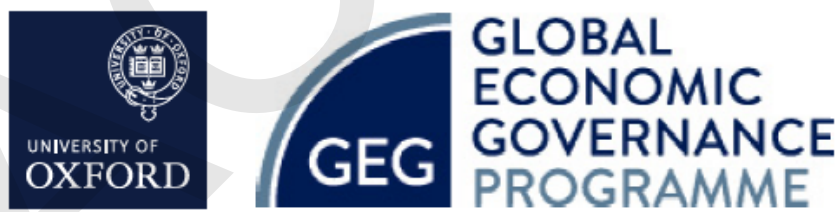


\title{
Improving the Fragile States' Budget
}

\section{Transparency: Lessons from Afghanistan}

\author{
Nematullah Bizhan ${ }^{1}$
}

\begin{abstract}
What drives improvements in the budget transparency of fragile states? By investigating the dynamics of budget transparency in post 9/11 Afghanistan, this paper demonstrates that factors such as budget reforms, aid conditionality, legislature and civil society (and media) demands for information partially explain the improvements in budget transparency, as measured by Open Budget Index. It is important how these factors interact. Government ownership, continuity and stakeholders' interests thus matter. Budget transparency tends to improve when the government leads the budget reforms, continuity in the reforms exists and multiple actors' interests-government, legislature, donors and civil society-are aligned and reinforce the transparency efforts.

This paper may offer two main lessons for fragile states. Firstly, the implementation of governance reforms, though complex, is possible in fragile states. When stakeholders easily understand a set of reforms, ownership is clearly defined and actors have consensus about the expected outcomes, the likelihood of success tends to be high. Secondly, as spending through the recipient budget tend to be more transparent than donors direct spending, as far as concern about transparency, it is more efficient for donors to channel a greater portion of their aid through the recipient budget.
\end{abstract}

The Global Economic Governance Programme is directed by Ngaire Woods and has been made possible through the generous support of Old Members of University College. Its research projects are principally funded by the Ford Foundation (New York), the International Development Research Centre (Ottawa), and the MacArthur Foundation (Chicago).

\footnotetext{
${ }^{1}$ Nematullah Bizhan is an Oxford-Princeton Global Leaders Fellow at the University of Oxford's Global Economic Governance Program and a Fellow at the Australian National University's Crawford School of Public Policy.

The author thanks the International Budge Partnership for supporting the case study of budget transparency in Afghanistan (2010) and the University of Oxford's International Political Economy's discussion group for valuable feedback on the earlier version of this working paper.
} 
Table of Contents

Introduction

Budget Process and Reforms

Legislature, Aid Conditionality, Civil Society and Media

Continuity and Alignment of Stakeholder's Interests

Concluding Remarks 


\section{Introduction}

This paper puts budget transparency in a governance reform's framework in fragile situations, arguing that budget transparency can contribute to enhanced legitimacy, improved oversight of government and informed electorate. Based on data drawn from primary government and private sources and 12 interviews-with Afghan government officials, journalists, Afghan legislature, civil society organisations (CSOs) members and aid agency officials, this paper uses Afghanistan as a case study to explore the transparency pattern in a fragile state.

State building in fragile states is complex. They suffer from a deficit of legitimacy and state weakness. Stewart and Brown define fragile states that are "failing or at risk of failing, with respect to authority, comprehensive basic service provision, or legitimacy" (Stewart \& Brown, 2010, p. 9). In such a context governance reforms, as Brinkerhoff argues, should target three areas: restoring legitimacy, establishing security, and building government effectiveness (Brinkerhoff, 2007).

Reconstructing legitimacy involves expanding participation and inclusiveness, reducing inequalities and promoting accountability, as well as delivering public services. Establishing security includes multiple processes, for example, the disarmament, demobilization and reintegration of ex-combatant, and peacekeeping operations. Rebuilding effectiveness concerns with issues related to functions and capacity of the public sector. These include service delivery and effective economic governance (Brinkerhoff, 2007).

Most highly fragile states are aid recipient at different degree. The total flow of official development assistance from donor countries to fragile states increased from US\$19 billion (in constant 2012 US dollars) in 2000 to US $\$ 49$ billion in 2012. Out of tope 20 aid dependent countries in the same year, for example, 13 of them were fragile (OECD, 2015, pp. 57-58). These states arguably pose major challenge to global security. Some donor countries have committed to channel a significant share of their aid to fragile states. David Cameron, the United Kingdom's prime minister, for example, announced a new policy in November 2015 to earmark half of the United Kingdom's aid to developing "fragile and failing" states to safeguard the UK's security from threats posed by these states (DFID \& HM Treasury, November 2015).

Where budget transparency stands? Transparency seems to be a necessary ingredient of good governance (Carlitz, 2013). Transparency contributes to enhanced legitimacy, improved oversight of government and informed electorate. Improvements in transparency may bolster legitimacy by demonstrating the state's willingness to operate openly and counters the rise of conspiracy thinking (Andrews, 2014; Benstead, 2014). In Presidential unitary states, such as Afghanistan, transparency provides the oversight agentslegislature, judiciary and civil society-with the necessary information to perform their oversight (Guinn \& Straussman, 2015, p. 2). Last but not least, transparency supports informed electorate to hold officials accountable at the ballot box (Heald, 2003).

What are the drivers of budget transparency? Budget transparency is an emerging sector and relatively understudied. Before the first Open Budget Survey in 2006, despite the fact that the International Monetary Fund used, comprehensive measures, the Code of Good Practices on Fiscal Transparency to conduct the countries fiscal transparency assessment since 1998 (IMF, 2015), reliable measures of budget transparency for large number of 
countries did not exist. Previous studies have largely used transparency as an explanatory factor for fiscal discipline, levels of corruption, or sovereign credit rating (Renzio \& Angemi, 2011). However, the key drivers of transparency have attracted little attention.

To asses budget transparency during budget formulation, legislature approval, execution and audit (Mikesell, 2013, p. 46), this paper uses Open Budget Index (OBI). While OBI measures are limited in comparison to the International Monetary Fund's Code of Good Practices on Fiscal Transparency, it is more focused and provides comprehensive data on the status of budget transparency around the world. Produced every two years in collaboration with civil society researchers in the countries covered, OBI surveys assesses how much timely and useful budget information governments make publicly available, and how accountable budget systems are in terms of the strength of official oversight institutions and levels of public participation. It uses a subset of survey questions on the public availability and comprehensiveness of budget information throughout the budget cycle. Each country included in the Survey receives an OBI score between zero (for the least transparent) and 100 (for the most transparent) (The International Budget Project, 2006). ${ }^{1}$

The OBI report in 2008 suggested a converse relationship between aid dependency and budget transparency. It found that high aid dependent countries suffer from a deficit of transparency. Eighteen countries that received above 10 percent of their gross national income (GNI) in foreign aid and 12 countries that received above five percent on average ranked 22 and 28 respectively by $\mathrm{OBI}$, in comparison to a score of 62 for non-aid dependent countries (IBP, 2008b, p. 18). However, it is simplistic to argue that the level of aid dependency may explain the level of budget transparency. Even in the 2008 OBl's survey significant variations exist. While in 2008, for instance, aid comprised above 15 and 22 per cent of Uganda and Rwanda's GNI, Uganda OBI score was 50 and Rwanda's 0 respectively. This variation demonstrates that other factors along aid dependency may have a crucial role.

In addition, based on the assessment of 16 high aid dependent countries, de Renzio and Angemis' research demonstrate that "rather than being linked to the level of overall development or of aid dependency per se, OBI scores are more closely correlated with democracy variables and with an index of donor engagement which tries to capture the quality rather than the quantity of aid flows to each country" (Renzio \& Angemi, 2011). Similarly, while Guinn and Straussman confirm that the foregoing champion and donor pressure hypotheses could explain improvement in budget transparency, they suggest that the legislature, especially when supported by donors to enhance reforms, can make a major contribution for improved transparency (Guinn \& Straussman, 2015, p. 5).

However, the identification of the multiple driving factors for budget transparency does not adequately explain the improvements in budget transparency without exploring the characteristics of such factors. In doing so, by using an in-depth assessment of the budget reforms and budget transparency in post 9/11 Afghanistan, this paper examines the driving factors of budget transparency and their characteristics.

While being an aid-dependent fragile state, Afghanistan's budget transparency has significantly improved post-2001. After the Taliban regime fell in late 2001, developments in Afghanistan took place in a highly aid dependent context. The $2008 \mathrm{OBI}$ survey scored Afghanistan 8 out of 100 , indicating that the Afghan government shared scant budgetary information with the public. Since then, despite increases in aid dependency, Afghanistan's budget transparency has dramatically increased (Figure 1). Aid's share of GNI in Afghanistan increased to 78 percent in 2011 from 72 percent in 2008 (Islamic Republic of 
Afganistan, 2012; Islamic Republic of Afghanistan, 2010; The World Bank, 2014). ${ }^{2}$ Meanwhile, its OBI score rose from eight in 2008 to 59 in 2012, slightly above the global average-same as Poland (an emerging donor) and above Pakistan, (ranked 58), with aid's share of GNI in Pakistan being one percent in 2012 (IBP, 2012b; World Bank).

However, OBI measures also have some limits in Afghanistan. It does not assess a large portion of aid that follows outside the government budget. Donors spent above four-fifths of their aid outside the Afghan government budgetary process using external budget mechanisms (Islamic Republic of Afghanistan, 2010). This type of aid fragmented the budget into core budget and external budget or on-budget and off-budget respectively, we use them interchangeably. In the former case, aid flows through the government budgetary system. In the latter donors directly spent their aid, bypassing the government budget. Also, limited access to the Internet make the publication of budgetary documents on the Finance Ministry's website largely inaccessible to most people. Despite these limits yet OBI provides a clear set of measures that is easy for different actors to understand and there is room for improvement by including the off-budget transparency assessments and by relying on traditional means of dissemination of the budgetary information, for example, through radio and televisions and universities.

Figure 1: Aid Flows as Share of GNI and OBI Score in Afghanistan

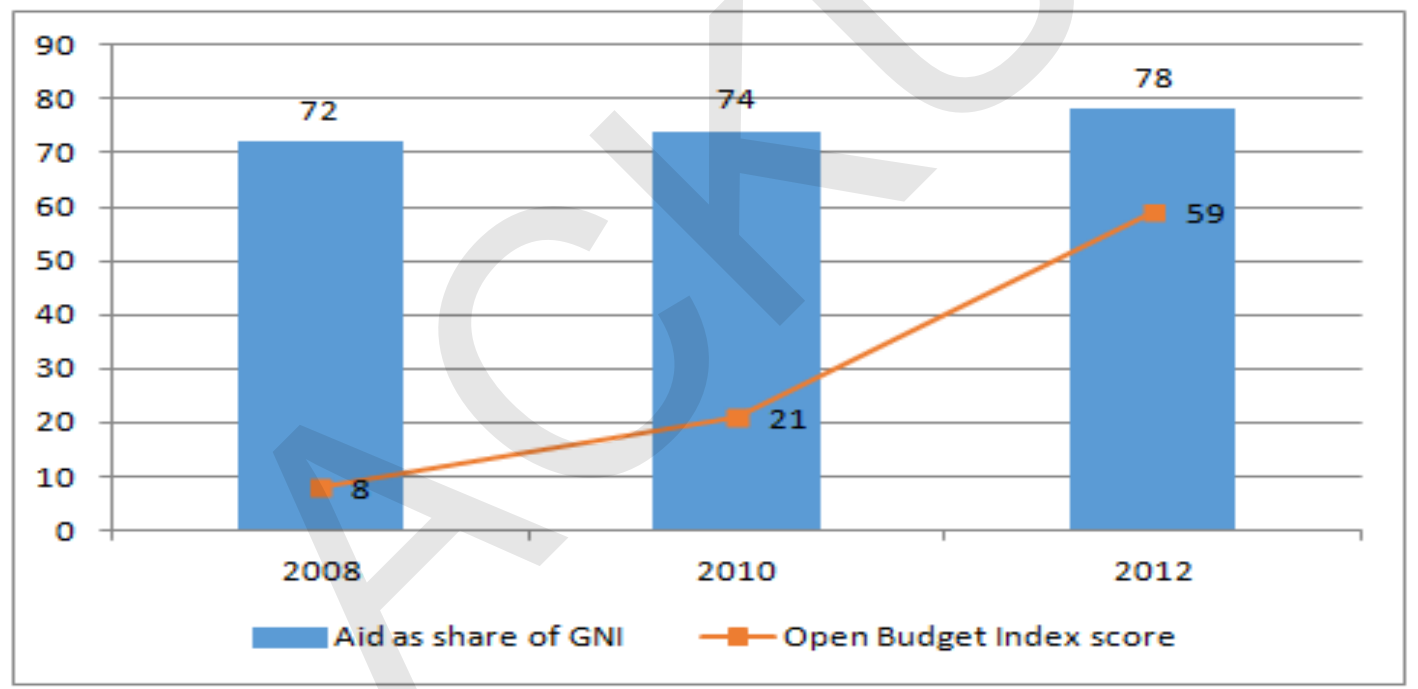

Source: IBP (2008a, 2010a, 2012a). Afghanistan's Finance Ministry (2014) and World Development Indicators (2015).

Afghanistan case shows that continued government-led budget reforms and the alignment of stakeholders' interests help to improve budget transparency. Important factors in this process are persistent budget reforms, aid conditionality to improve the budget process and availability of donors' technical assistance, as well as the legislature and civil society demands for information, media pressure on the government, and adaptation of OBI as an easy way to measure transparency contributed to improve budget transparency. Continuity in budget reforms and the existing of a mutual interest between the Afghan government, legislature, donors, civil society actors and medias' interests reinforced the transparency efforts. The following sections explore the budget process and budget transparency patterns in Afghanistan and then makes some concluding remarks. 


\section{Budget Process and Reforms}

Although Afghanistan inherited unfavourable conditions, achievements in the area of budget reforms post 2001 were significant. The alignment of foreign donors and the Afghan governments' interests and continuity in their efforts to reform the budget improved the budget process and established a necessary pre-condition to enhance budget transparency.

Historically, the government's institutional capacity with regard to public financial management and transparency was weak, and various local actors were not obliged to properly report and account for their use of public money (Riā'sat-i 'Aumumī Aidārah-i Aumūr Va Dār al-ainshā-yi Shorā-yi Vazirān (Office of Administrative Affairs and Cabinet Secretariat), 1388 Solar Hijra Calender [2009]). Information technology infrastructure did not exist. The government departments did not use computers-even the Finance Ministry did its calculations manually (S. Ghani \& Bizhan, 2009). The bureaucrats treated budget documents as mahram (secret) information (Interview, December 2011). In particular, the Taliban regime (1996-2001) kept its budget and sources of revenue secret while though producing a budget in the form of a general statement for internal use (Carnahan, Manning, Bontjer, \& Guimbert, 2004).

Budget in Afghanistan is comprised of ordinary (operating) and development (investment) components. The Finance Ministry leads budget formulation and execution. Primary budgetary units, 26 ministries and 35 independent public institutions and commissions, send their budget proposals to the Finance Ministry. The budget committee, comprising representatives from the Ministries of Finance, Economy, Foreign Affairs, and Independent Public Administration and Civil Service Commission, assesses the budget proposals with the concerned institutions in budget hearings. After the Minister's Cabinet approves the draft budget, the Finance ministry send the budget for the legislature approval (Directorate General Budget).

The preparation of a comprehensive budget in 2004 was a major challenge. While Afghanistan needed to meet the international standards in budget formulation and execution to be eligible for budget support aid, the Finance Ministry and other government ministries and departments had very limited capacity. In addition, the government hardly had access to external budget information, especially in the first year's fall of the Taliban regime. Also, the government did not have reliable information about its employees and the details of operational cost. Therefore, the government initiated the restructuring, capacity building and reforms of the Finance Ministry.

Massive international aid flowed into the country after 2001 to fund the reconstruction and stabilization efforts. Aid on average has comprised 77 per cent share of the gross domestic product (GDP) from 2002-2010 and average has financed 98 percent of government development budget and 45 percent of operating budget from 2003-2010 (Bizhan, 2013, p. 160; Islamic Republic of Afghanistan, 2010, p. 103). Budget became a central tool for coordinating and realizing national policies, but it did not represent all of the aid flows to the country. Budget was divided into on- and off-budgets.

A large portion of aid was channelled outside government budget through the externalbudget system, over which the Afghan government and legislature had no control or oversight (Osmani). This type of aid fragmented the budget along core-budget and external budget. The government defined on-budget as "the portion of the national budget that [was] 
controlled by the government ... and the government [was] accountable for reporting on the expenditure of these funds" (Transitional Government of Afghanistan, October 2004 4.). Domestic revenue, Trust Funds such as Afghanistan Reconstruction Trust Fund (ARTF) and Law and Order Trust Fund (LOTFA), and the grants and loans from the World Bank and the Asian Development Bank were on-budget. Operating budget and a small part of development budget were on-budget. However, only a small portion of aid that came onbudget was discretional because donors earmarked the bulk of their aid for specific projects or decided where it was to be spent. ${ }^{3}$

On the other, off-budget aid was channelled to projects managed directly by UN agencies, NGOs and private contractors. A great portion of aid by major bilateral donors, like the US and Japan, and humanitarian assistance were spent off-budget (Lockhart, 2007, pp. 20-22). The government defined off-budget as "the portion of the budget that flow[ed] outside of the government accounts."

Donors saw the off-budget aid as a mechanism to substitute for the Afghan government limited capacity and to avoid the risk of waste due to corruption in the Afghan public sector (Transitional Government of Afghanistan, October 2004 4.). The core-budget suffered from a poor development budget execution rate. Between 2004 and 2010, on average the government spent 43 per cent of its approved development budget. ${ }^{4}$ This was mainly due to ineffective national procurement system and the complexity of the donors' procurement systems, bureaucratic delays, and deficit in government capacity. While external-budget aid has slightly improved the aid delivery, it has increased the cost of projects and has undermined the principles of transparency and accountability because it remained less accessible to public and the government. In addition, off-budget aid diverted political and financial resources to reform and build the capacity of state institutions.

Between 2001 and 2010 , only US $\$ 10$ billion out of a total US $\$ 65$ billion of foreign assistance was channelled through on-budget using the government budget system; the rest went directly from donors to implementing agencies through parallel mechanisms (Islamic Republic of Afghanistan, 2010, p. 101). The Afghanistan Assistance Coordination Agency and then the Development Budget and External Relation Unit in the Finance Ministry's Budget department coordinated the flow of aid to Afghanistan (Carnahan et al., 2004; Welsh \& Woods, 2007, p. 269). The reliance of donors on off-budget mechanisms for aid delivery differed. The US channelled above 90 percent of its aid off-budget. Others such as Asian Development Bank and World Bank fully channelled their aid through on-budget. Donors like Denmark channelled above half (58 percent) their aid on-budget (Islamic Republic of Afghanistan, 2010).

The government, hoping to earn the trust of the international community and to reignite public confidence in the Afghan state, reformed the budget systems (Ashraf Ghani \& Lockhart, 2008, p. 138). It aimed to improve public resource management and to assure donors that their aid money would be channelled through a credible budget system. Plus, the government hoped to differentiate itself in the public eye from former regimes that had kept the budget a secret and based expenditure on political agendas and the self-interest of public officials (Interviews by Author, November 2011-April 2012).

The government implemented major budget reforms to improve budget formulation and execution between 2002 and 2005. Access to aid and technical support contributed to the budget reforms. The government adopted a policy of no deficit funding of the budget; centralized revenue collection and budget allocation and reporting; identified the actual 
number of government employees; established a Donor Assistance Database and Public Financial Management Information System. It agreed on a new approach in development expenditures for coordination of feasibility studies of infrastructure projects and the role of government in the economy, especially in privatization of the state-owned enterprises. ${ }^{5}$

Additionally, the government adopted a new Public Financial Management Law and a policy of equal opportunity across the county. The Finance Ministry initiated a process to report on the fiscal conditions of the country on a regular basis to the Cabinet and on an ad hoc basis to the public through media and the Finance Ministry's website (see Asrhaf Ghani, Lockhart, Nehan, \& Massoud, 2007, pp. 175-180). ${ }^{6}$

The United States Agency for International Development (USAID), the World Bank, the U.K. Department for International Development (DFID), and the United Nations Development Programme (UNDP), supported the public financial management reforms, with the budget being a main focus. Though budget transparency was not the prime objective of donor support or a prerequisite for donor assistance, the issue was indirectly addressed in their support projects.

The result of support for public financial management reforms in the form of timely, comprehensive, and accessible budget reports became visible later (see IBP, 2010b, p. 40). The World Bank supported the installation and operationalization of Afghanistan Financial Management Information System. It helped to manage the operating budget and to produce detailed monthly reports on the execution of the budget especially during 2004 budget preparation. In addition, UNDP supported the establishment of a donor assistance database, an automated information management system designed in 2002 to improve efficiency and transparency of national development planning and coordination of donor activities in the country (Synergy International Systems, 2015).

These reforms were accompanied by restructuring of the Finance Ministry's Budget General Directorate which then conducted merit based recruitment, and for the first time invested in information technology. Development Budget and External Relations Unit has championed the budget reforms and the promotion of merit based appointments. The Finance Ministry trained other ministries and departments involved in the budget process to enhance budget formation and execution. These attempts helped to improve the budget process.

While external pressure between 2001 and 2004 may have prompted the Afghan government to take steps to make the budget more transparent, the government also had its own reasons for doing so. In the past the legacy of conflict in the country, particularly as it related to the misappropriation of public funds, seriously undermined the legitimacy of the governments. Afghanistan focused on three pillars necessary for post-conflict governance reforms: re-establishing legitimacy, establishing security and creating effectiveness. The Afghanistan National Development Strategy three priority pillars were aligned with these principles: improving security, governance and socio-economic development (Islamic Republic of Afghanistan, 2007). The government had a strong incentive to use the budget as a tool to gain public trust and bolster its legitimacy.

The Finance Ministry's leadership and an emerging group of young professionals, educated in Afghanistan and outside, along their counterparts, played a crucial role in ensuring the success of the public financial management reforms. These individuals contributed significantly to ensuring that the ministry was moving in the right direction. Young professionals in the budget department gained the trust of the clients and government. Eight 
members of the Budget department were later promoted to deputy ministerial positions in different ministries, including one in the Finance Ministry. ${ }^{7}$

The budget department also embarked on a process of raising budget awareness among civil society organisations at the provincial level. An important initiative was launched in 2004 when the first National Conference on Civil Society and Budget was held in Kabul. ${ }^{8}$ Additionally, the first Public Financial Report was prepared and made public in 2004 (Transitional Government of Afghanistan, October 2004). However, the follow up on these initiatives has been poor especially after change in the leadership of the Finance Ministry in early 2005.

Although the Enacted Budget (a legal document authorizing the government to raise revenue, make expenditures and incur debt), Mid-Year Budget Review (an overview of budget in midpoint and of any changes in economic assumptions), and information about donors were made available online through the Finance Ministry's website-the content and format of these documents changed regularly-and there were no standards for the quality of the content and no firm deadlines about when the information should be posted. Audit report, an independent evaluation of the government's accounts by Afghan Supreme Audit Office, was not public.

The government initiated and owned the budget reforms while donors provided technical assistance. The political dynamic to reconstruct Afghanistan and to build the confidence of the public and donors on the government brought the budget in the centre of attention of key actors in Afghanistan. The important aspect of the process was that the donors and the governments' interests were aligned. These reinforcing attempts helped to improve the budget process and to establish a necessary pre-condition to improve budget transparency. 


\section{Legislature, Aid Conditionality, Civil Society and Media}

Multiple actors' demands and public dissonant from the Karzai government because of widespread corruption reinforced the transparency efforts. The Presidential and Parliamentary elections in 2004 and 2005 respectively, the civil society, including media, demands for transparency and the newly established legislature's demand for detailed budgetary information increased the pressure on the government to prepare more detailed budget and to enhance transparency. Donors continued to support budget reforms and also, though much less than the support for executive, provided technical support to the legislature. Except the effects of the Finance Ministry's leadership change that slowed down the pace of public financial management reforms, continuity and alignment existed in the stakeholders' efforts for improving the budget process.

The budget reforms experienced a relatively slow pace in mid 2005. The follow up on the earlier initiatives to improve public participation in the budgetary process, such as dialogue with civil society organizations, was poor as priorities changed for the new leadership of the Finance Ministry and the security situation in the country deteriorated from 2005 (U.S. Government Accountability Office, 2009). The government and major donors, therefore, focused their attention on efforts to stabilize the country. While these developments may have limited the efforts to strengthen transparency, they did not terminate such efforts.

However, the new political dynamics reignited the effort to improve transparency. The establishment of the new parliament in 2005, consisting of a lower house (wolesi jirga) and an upper house (meshrano jirga) or Senate, helped to improve the budget process in the coming years. The parliament stipulated that budgetary information must be shared with the members of parliament prior to budget hearings. But even though the capacity of the parliament to conduct in-depth analyses of the budget was limited, the convening of the new parliament in January 2011 led to improvements in the content of the budget documents, as well as their availability in local languages.

The parliament was asking pertinent questions in parliamentary budget hearings. Questions focused on such issues as "why the budget for one ministry or province is higher than the other one", led the Finance Ministry to prepare a more detailed budget to justify its answers (Osmani). However, while member of the lower house were interested in the budget at a provincial level, they paid little attention to priorities at national level (Interview, November 2011). Unfortunately, individual members of the lower house also often forfeited budget transparency by dealing with the executive directly behind closed doors to lobby for resources for their own constituencies (Interviews by Author, November 2011-April 2012; Surhke, 2011).

The Parliament, however, officially had a limited role in resource allocation and budget oversight. Most of the agreements on project funding were reached between the executive and the country's foreign donors. Additionally, external budget was outside the scrutiny of the parliament. The information that the parliament received on expenditures lacked the necessary details for further oversight and scrutiny. The core-budget reports, for instance, included overall allocations and expenditures of projects but no detailed data, making it difficult for the parliament to examine failures and hold the responsible agencies accountable. Instead, they were relegated to making generalized critical statements (Interviews by Author, November 2011-April 2012). 
The civil society activists and media also put pressure on the government to improve budget transparency. They bore witness to the low quality of construction projects in their communities and to the misappropriation of project funds. The failure of the government in fulfilling its constitutional obligation of promoting accountability made the civil society and the media vocal critics of the government and its lack of commitment to fighting corruption. In response, following the first Presidential elections President Hamid Karzai (2001-2014) created "accountability week" in 2005-a week in November every year during which members of the cabinet had to report to the public on their performance. In practice, however, many observers found that the week was treated more as a "reporting week" than an "accountability week." (Habib, November 20, 2005). The fact that the ministers were not openly sharing their performance reports with the media in advance made it difficult for the media to engage constructively on the issues. Thus, the media and civil society activists were critical of the government for its failure to tackle corruption (Faramarz, February 10, 2011; Torabi).

The efforts for improving budget largely focused on internal documentation, improving fiduciary controls, and making data available for donors and those responsible for policy formulation and decision-making. Little attention was paid to whether or not budget documents were accessible to the public. Even international financial institutions paid more attention to the fiduciary controls of the public financial management system than to whether or not the public had access to budget documents or were able to engage in the budget process (Ishihara, Sisk, Fernando, \& Jensen, May 2008). This might have been a necessary step during the initial phase of institution building.

While the Finance Ministry was producing most of the necessary budgetary documents, it was not making all of them public. As the Deputy Finance Minister Mustafa Mastoor put it: "Previously, we did not publish these documents although we had them available, because we were not aware of the international budget ... [transparency measures]."(Faramarz, February 10, 2011). In 2008, the open budget survey found that of the eight key budget documents that should have been made public according to OBI, only four were published on the Finance Ministry's website (Table 1): the Enacted Budget, the Mid-Year Review, the Year-End Report (information about the actual budget execution based on enacted budget), and the In-Year Reports (monthly or quarterly budget reports). One of the most important documents-the Executive's Budget Proposal, which contains the government's plans for raising and spending public funds for the upcoming year-was not made public. The proposed budget should have been made available to the legislature and the public at least three months before the start of the budget year, allowing sufficient time for review and public debate (Faramarz, February 10, 2011).

Furthermore, while Afghanistan was publishing In-Year Reports and a Mid-Year Review as found in 2008, these documents were not comprehensive enough to provide an adequate update on how the budget was being implemented during the year. Similarly, while the government was producing a Year-End Report, it did not contain enough information for a comparison to be made between what was budgeted and what was actually collected and spent during the year. In addition, because the Audit Report was not published, the civil society and the broader public did not have access to information on whether the measures to address problems identified in the audit were implemented successfully. Despite budget reforms having slowed down, the new parliament demands for detailed budgetary 
information and the public pressure to improve transparency reignited the momentum to improve the budget transparency. 


\section{Continuity and Alignment of Stakeholder's Interests}

Continuity in the budget reforms and alignment of stakeholders' interests to enhance the budget process further reinforced the transparency efforts. The government build up on the earlier budget reforms, donors provided technical support, and the civil society actors further pressed the government to improve budget transparency. Donors and the government agreed on specific measures to improve budget transparency.

Once the 2008 findings of the Open Budget Survey established a baseline on-budget transparency, the government, donors and the civil society organisations built on it. The government took the lead in improving budget transparency. It, among others, aimed to improve its image among the international community and public by improving its OBI score; civil society organisations demanded increased transparency and donors made their aid conditional to improvements in budget transparency. These efforts reinforced the transparency efforts.

Subsequently, despite increases in aid dependency, Afghanistan's budget transparency has dramatically increased. Aid's share of GNI in Afghanistan increased to 78 percent in 2011 from 72 percent in 2008 (Figure 1). Meanwhile, its OBI score rose from eight in 2008 to 59 in 2012, slightly above the global average-same as Poland (an emerging donor) and above Pakistan, (ranked 58), with aid's share of GNI in Pakistan being one percent in 2012 (IBP, 2012b; World Bank). Table 2 below compares the developments of budget transparency trend.

Table 1: Availability of Key Budget Documents (2008, 2010, 2012)

\begin{tabular}{|l|l|l|l|l|l|l|}
\hline \multirow{2}{*}{ Budget Documents } & Status & Availability & Status & Availability & Status & Availability \\
\cline { 2 - 7 } & \multicolumn{2}{|c|}{2008} & \multicolumn{2}{c|}{2010} & \multicolumn{2}{c|}{2012} \\
\hline Pre-budget statements & Prepared & No & Prepared & Yes & Prepared & Yes \\
\hline $\begin{array}{l}\text { Executive's budget } \\
\text { proposal }\end{array}$ & Prepared & No & Prepared & No & Prepared & Yes \\
\hline Citizens budget & No & No & Prepared & Yes & Prepared & Yes \\
\hline Enacted budget & Prepared & Yes & Prepared & Yes & Prepared & Yes \\
\hline In-year reports & Prepared & Yes & Prepared & Yes & Prepared & Yes \\
\hline Mid-year review & Prepared & Yes & Prepared & Yes & Prepared & No \\
\hline Year-end reports & Prepared & Yes & Prepared & Yes & Prepared & Yes \\
\hline Audit report & Prepared & NO & Prepared & Yes & Prepared & No \\
\hline
\end{tabular}

Source: (IBP, 2008a, 2010a, 2012a)

Out of eight key budgetary documents, six of them, except Mid-Year Review and Audit Report, were made public in 2012. Despite improvement in budget transparency, the government only share some information on the annual national budget and financial activities, making it hard for citizens to hold government accountable for its management of the public purse. While the oversight strength of Afghan Supreme Audit Office and legislature was strong and moderate respectively, the public had limited opportunities for participation in national budget decision-making (IBP, 2012a).

The government prioritized budget transparency in 2008. OBI established a baseline and provided a simple framework to measure the progress (IBP, 2008a). ${ }^{9}$ The findings of the first Open Budget Survey in 2008 were unexpected for the Finance Ministry and exposed the 
government shortcomings in the area of transparency. It found that the Afghan government provided little budgetary information to the public during the annual budget cycle. It also concluded that access to detailed budget information regarding the government's progress in carrying out particular projects or activities was limited (IBP, 2008a).

Other factors also undermined budget transparency. These included a lack of consolidated provincial budgets; the absence of details in the national budget beyond overall allocations and expenditure on projects (Interviews by Author, November 2011-April 2012). This situation was exacerbated in the absence of law on the right of access to information in Afghanistan, codified only in 2014 (The Danish Institute for Human Rights, December 3, 2014,). This meant that access to information depended entirely on the discretion of ministers and government officials, who were not legally obliged to provide it. This situation, along with most aid being external-budget, made it difficult for Afghan citizens to hold the government to account with regard to how it manages public funds.

No record is available to show that any internal or external actor publicly opposed budget transparency. However, some transactions from donors to politicians and strongmen, as we noted before, through off-budget remained hidden from public. Although many political parties, old and new, also called for accountability and transparency from the government, they themselves were not accountable concerning reporting of their income and activities to the public.

The government, which was surprised by the outcome of the 2008 Survey, was concerned about the image that this would present to donors and the public. Because the Survey provided a simple and easy strategy for improving budget transparency, as well as a means of assessing progress, the government took note of the OBI indices and put measures in place to improve its ranking. These measures included: identifying the budget documents which should be published and the key deadlines for publication; improving the content of these documents; establishing an internal monitoring process through the Public Financial Management Roadmap; assigning a liaison officer to follow up on the budget transparency measures; and reporting regularly to the Committee of Ministers and the Joint Coordination and Monitoring Board-a high-level board that includes donors and the governmentthrough the National Priority Programme's quarterly updates (Islamic Republic of Afghanistan, June 2011).

Major international donors and the Afghan government saw the $\mathrm{OBI}$ as an important tool for providing a baseline from which to measure progress on increasing budget transparency. ${ }^{10}$ This consensus about the importance of budget transparency resulted in a shift in public financial management priorities in 2010 (Government of Afghansitan, July 14, 2010, pp. 3-4). At the Kabul International Conference in June 2010, the government presented a Public Financial Management Roadmap, which was then endorsed by its international partners. The roadmap focused on "strengthening the budget in driving effective delivery of key priority outcomes; improving budget execution; and increasing accountability and transparency" (Government of Afghansitan, July 14, 2010, p. 3).

In 2010, foreign donors committed to channelling up to 50 percent of their funds through the government budget on the condition that the government made its budget more transparent, as measured by the $\mathrm{OBI}$, and increased its spending capacity. The government, in turn, committed to drawing up a credible development plan, increasing its budget capacity, and improving transparency with the intermediate goal of scoring 30 in the OBI by June 2011 (Government of Afghansitan, July 14, 2010, p. 3). In 2011, the government drafted a 
Citizens Budget, a nontechnical presentation of budget to the public, and made it public (Ismalic Republic of Afghanistan).

In addition to UNDP's support project for budget, advisers of an Adam Smith International's project, funding by DFID, helped the budget department to draft budget documents and amend the existing documents. Furthermore, a USAID project-Afghanistan Parliamentary Assistance Project-provided technical assistance to the legislature by working closely with the parliament's budget and economic committee (Interview, January 25, 2012). The Finance Ministry received more technical assistance than any other Afghan civil state institution (World Bank, July 16, 2011), which raises the concerns about the long term sustainability of the reforms.

Media and civil society organisations continued to press the government to further improve transparency. Their pressure increased when corruption became endemic and government failed to implement firm anti-corruption measures. ${ }^{11}$ Thus, along with local and international media attention, whilst limited, they challenged the government to become more transparent as corruption cases were exposed through investigative stories. The Afghan media, which is still very young, has had a positive impact by demanding budgetary information and by focusing on corruption cases. The government, which has a fear of being portrayed negatively in the media, lest it lose public support in insurgent strongholds, has been increasingly forced to share information on its performance and the budget (Interviews by Author, November 2011-April 2012).

The ministry also began an on-going process of raising awareness about the budget among civil society organisations through workshops, and including these organizations in budget preparation. At the request of the Finance Ministry and the United Nations Assistance Mission in Afghanistan (UNAMA), two civil society organisations' representatives began attending the government policy and budget meetings. While this was a step in the right direction, the representatives claimed that they were not able to access pertinent information prior to the meetings, and that, although their views were welcomed, there has been no indication that they had been taken into account when policy and budget decisions were made (Niazi, November 2011). It could be argued that the inclusion of the civil society organisations was more a gesture of goodwill than a serious attempt to involve civil society in the decision-making process. The government still needs to establish a legitimate channel for public engagement in the formal budget process.

Some civil society organisations initiated projects to monitor budget transparency. The researchers of Integrity Watch Afghanistan and Open Budget Partners, non-governmental and non-profit organisations respectively, established contact with the Finance Ministry to discuss budget transparency, published their analyses of the budget, as well as organizing public awareness campaigns that incorporated meetings and workshops. Integrity Watch Afghanistan, for example, organized workshops in Herat province for 80 local monitors, who were doing budget tracking at a grassroots level, and also trained between 30 and 40 local public officials (Torabi). Additionally, the Equity for Peace and Democracy provides an independent assessment of the government budget. Afghan Civil Society Forum provides a coordinated platform for civil society organisations to assess government policies and performance (ACSFO; EPD). There might be more civil society organisations with a focused agenda on transparency and accountability, which this paper could not highlight; however, further research should reveal their activities and impacts in the area of transparency and accountability. 
Despite the major achievements, transparency efforts and $\mathrm{OBI}$ measures have some limits. The Afghan government's transparency efforts are largely dependent on donor funded technical assistance, and donor interests are shifting. In addition, civil society organisations have limited resources, are depended on donor money and have limited capacity to carry out countrywide public awareness campaigns. ${ }^{12}$ Thus it will take time, and an investment of considerable energy in promoting active participation in the budget process, for this to change.

In addition, low literacy rate, 31 percent in 2011 (World Bank), and very limited access to internet pose challenge for the effectiveness of the $\mathrm{OBI}$ measures, which largely relies on publicity of budgetary documents through the government websites. To bridge this divide, the government should consider printing budget documents and distributing them to public libraries and universities, as well as alternative means of communication, such as audio and visual media. The problems around access to information are compounded by the fact that there is no integrated unit in the Finance Ministry-or in any other ministry-that responds to demands for information. The result is that if someone contacts the ministry in an attempt to obtain information, he or she will most likely be referred to another department, making it difficult to access information in a timely manner, if at all. In many cases, public servants regard the sharing of information as a favour instead of a legal obligation (Interviews by Author, November 2011-April 2012).

The structure of budget is also problematic. Budget is divided along core- and external budgets. Donors directly spend a large portion of their aid through external budget mechanisms. OBI measures do not assess the transparency of aid donors. While donors, who want to know that aid money is being spent effectively, have been demanding more transparency in core-budget allocations and expenditures, they have paid little attention to making the externally aided projects more transparent.

An Integrity Watch Afghanistan report suggests that external-budget transactions are less transparent than on-budget ones, and that donors share less than 35 percent of the information on their activities within the country with the Afghan people and government (BBC Persian - Afghanistan, November 21, 2011). The report also claims that donors do not share project documents, which makes oversight of the projects through public engagement difficult, undermining the principles of transparency (Torabi). Aid from the US, for instance, remained less transparent which comprised about 65 percent of total aid to the country from 2002-2010 (Islamic Republic of Afghanistan, 2010, p. 104). But this situation greatly improved especially after the US Congress created the office of Special Inspector General for Afghanistan Reconstruction in 2008. The inspector general has provided an independent oversight for Afghanistan reconstruction projects and activities financed by US government and made the reports publicly available (SIGAR).

Despite the limitations, as noted earlier, continuation of the government-led efforts to reform and to strengthen the budget process, alignment of the interests of the Afghan government, legislature, civil society activists, media, donors contributed to improved budget transparency. While sustainability of such efforts remains an area of concern but transparency efforts tend to continue. The case of Afghanistan shows that multiple factors may contribute to improved budget transparency but there is a high tendency to further improvements of transparency when there is continuity in the budget reform efforts, different actors' interests are aligned and reinforce transparency. 


\section{Concluding Remarks}

What are the main drivers of budget transparency in fragile states? This paper demonstrates that multifaceted factors and how they interact can explain the improvements in budget transparency. Budget reforms, aid conditionality, legislature, civil society and media demands for information partially explain the improvements in budget transparency. We found that the transparency efforts tend to be more successful when along with transparency stimulating factors a particular dynamism exists in which the government ownership is ensured. As well continuity exist in the reform efforts and the budget stakeholders'government, legislature, donors, civil society and media-interests are aligned and reinforce the transparency efforts.

However, the size of foreign aid does not explain the level of budget transparency. The 2008 OBI survey's finding, which claims that high aid dependency is conversely correlated with budget transparency, does not explain the complexity of the budget process and budget transparency. We noted that multiple factors along with a particular dynamism that reinforce or undermine the transparency efforts may explain budget transparency. Aid dependency thus could be associated either with poor or improved budget transparency.

We may draw lessons on how to reform governance, and which aid delivery channels could be more transparent in fragile states. Firstly, the implementation of reforms, though complex, is possible in fragile contexts. When stakeholders easily understand a set of reforms, ownership is clearly defined and actors have consensus about the expected outcomes the likelihood of success tends to be high. Secondly, as spending through the recipient budget tends to be more transparent than the donors' direct spending outside the recipient budget; therefore, to ensure transparency, it is more efficient for donors to channel a greater portion of their aid through the recipient budget. 


\section{Notes}

${ }^{1}$ When the $\mathrm{OBI}$ researchers fill the questionnaires about the status and availability of budgetary documents to the public, they rely on governments to collect such information. While this may make the process biased as the governments may provide false information to portray a positive image, the provision of evidence to support the data and availability of such data and the questionnaires for public minimizes the risk of biasness.

2 The official development assistance (ODA) does not include security (and antiterrorist) expenditures. The aid's share of GNI in the World Development Indicators thus shows a lower percentage for Afghanistan. The author has included security expenditure in the aid's share of GNI for Afghanistan.

${ }^{3}$ For example, of the US $\$ 70$ billion which the US Congress approved for assistance to Afghanistan since 2001 , US $\$ 2.1$ billion was on-budget, of which only US $\$ 46$ million or less than one per cent was at the discretion of the Afghan government (Ministry of Finance of Afghanistan, July 26, 2011).

${ }^{4}$ Data from the Ministry of Finance on the core development budget execution rate and calculation by author, 2011.

${ }^{5}$ Furthermore, government procurement was initially outsourced to an international company, Crown Agents, to handle development project procurement. This role was later transferred to an independent procurement unite called Afghanistan Reconstruction and Development Services (ARDS) which was established under the Economy Ministry in 2003.

${ }^{6}$ Crown Agents, a British international development specialist organisation, was contracted to assist the government to handle the procurement of development projects in the first years after the fall of the Taliban regime, however this role was shifted to a newly established unite first under the ministry of reconstruction of the Afghanistan and then the ministry of economy when the former was merged with Planning Ministry and formed the Minister of Economy. See Crows Agent see (Crowns Agent, n.d) (and Afghanistan Reconstruction and Development Services (ARDS), n.d).

${ }^{7}$ Author's personal notes.

${ }^{8}$ This event was recorded. Video of the Conference, Civil Society and Budget National Conference (2004), and author's personnel notes 2004-2005.

${ }^{9}$ The IBP's Open Budget Initiative included Afghanistan in its Survey for the first time in 2008. The initial point of entry was an email exchange between the IBP and the Afghan Finance Ministry.

${ }^{10}$ The emphasis at the Kabul International Conference (July 2010) was for the Afghan government to take firm anti-corruption measures. The Public Financial Management Roadmap (July 2010), which was endorsed by donors, highlighted the OBI as a successful means of assessing budget transparency in Afghanistan. See (Islamic Republic of Afghanistan, July 20, 2010, p. 4) and (Government of Afghansitan, July 14, 2010, p. 3).

${ }^{11}$ Donors were mostly using the international platforms on Afghanistan, such as the Kabul International Conference (June 2010), calling on the government to take firm measures against corruption.

${ }^{12}$ See also Afghanistan Development Advocacy Network (ADAN), "Position Paper to NATO Summit on Afghanistan 20-21 May 2012", (Kabul, 2012). 


\section{References}

ACSFO. About ACSFO: Background. Retrieved from

http://www.acsf.af/english/index.php?option=com_content\&view=article\&id=1:background\&c atid=29\&ltemid $=3$

Afghanistan Reconstruction and Development Services (ARDS). (n.d). Who we are? Retrieved from http://www.ards.gov.af/index.php

Andrews, M. (2014). Why Distributed End Users Often Limit Public Financial Management Reform Success, Workding Paper 283. Center for International Development, John F. Kennedy School of Government, Harvard University.

BBC Persian - Afghanistan. (November 21, 2011). Fālīat Hā-i Nihād Hai' Kūmak Dihindah Dar Afghanistan Shīfaf Nīst (Donor Activities are not Transparent in Afghanistan). Retrieved from

http://www.bbc.co.uk/persian/afghanistan/2011/11/111121_k01_afg_aid_transparency.shtml

Benstead, L. (2014). Monkey Cage: Why Some Arabs Don't Want Democracy. The Washington Post. Retrieved from http://www.washingtonpost.com/blogs/monkeycage/wp/2014/09/30/why-some-arabs-dont-want-democracy/

Bizhan, N. (2013). Afghanistan: Foreign Aid and State Building, 2001-2009. The Australian National University, Canberra.

Brinkerhoff, D. W. (2007). Governance in Post-conflict Societies: Rebuilding Fragile States. London: Routledge.

Carlitz, R. (2013). Improving Transparency and Aaccountability in the Budget Process: An Assessment of Recent Initiatives. Development Policy Review, 31(s1), s49-s67.

Carnahan, M., Manning, N., Bontjer, R., \& Guimbert, S. (2004). Reforming Fiscal and Economic Management in Afghanistan. Washington: World Bank.

Crown Agents. (n.d). Where we work: Afghanistan. Retrieved from http://www.crownagents.com/Afghanistan.aspx

DFID \& HM Treasury. (November 2015). UK Aid: Tackling Global Challenges in the National Interest.

Directorate General Budget. Budget Process. Retrieved from

http://www.budgetmof.gov.af/index.php/en/2012-12-06-22-51-13/budget-process

EPD. About EPD. Retrieved from http://www.epd-afg.org/

Faramarz, A. W. (February 10, 2011). Afghanistan More Open About Finances. Retrieved from http://iwpr.net/report-news/afghanistan-more-open-about-finances

Ghani, A., \& Lockhart, C. (2008). Fixing Failed States: A Framework for Rebuilding a Fractured World. New York: Oxford University Press.

Ghani, A., Lockhart, C., Nehan, N., \& Massoud, B. (2007). The Budget as the Linchpin of the State. In J. K. Boyce \& M. O'Donnell (Eds.), Peace and the Public Purse: Economic Policies for Postwar Statebuilding (pp. 153-184). Colorado: Lynne Rienner.

Ghani, S., \& Bizhan, N. (2009). Contracting out Core Government Functions and Services in Afghanistan. In OECD (Ed.), Contracting Out Government Functions and Services:

Emerging Lessons from Post-Conflict and Fragile Situations (pp. 97-113): OECD.

Government of Afghansitan. (July 14, 2010). Public Financial Management (PFM) Roadmap. Ministry of Finance.

Guinn, D. E., \& Straussman, J. D. (2015). Improving the Budget Process in Fragile and Conflict Ridden States: Two Modest Lessons from Afghanistan. Public Administration Review.

Habib, A. (November 20, 2005). Awalīn Rūzi "Hafta' Hasābdihay" Dawlat' Afghanistan (the First Day of "Accountability Week" of the Afghan State). BBC Persian. Retrieved from 
http://www.bbc.com/persian/afghanistan/story/2005/11/051120_v-adfgahn-accuontibility1.shtml

Heald, D. (2003). Fiscal Transparency: Concepts, Measurement and UK Practice. Public Administration, 81(4), 723-759.

IBP. (2008a). Open Budget Index 2008: Afghanistan. Retrived from

http://www.internationalbudget.org/wp-content/uploads/2011/04/cs_afghanistan.pdf

IBP. (2008b). The Open Budget Survey of 2008: Open Budgets Transform Lives.

Washington DC.

IBP. (2010a). Open Budget Index 2010: Afghanistan. Retrived from

http://www.internationalbudget.org/wp-content/uploads/2010/10/OBI2010-Afghanistan1.pdf

IBP. (2010b). The Open Budget Survey 2010: Open Budgets Transform Lives. Washington DC.

IBP. (2012a). Open Budget Index 2012: Afghanistan. Retrived from

http://www.internationalbudget.org/wp-content/uploads/OBI2012-AfghanistanCS-English.pdf IBP. (2012b). Open Budget Survey 2012: Open Budgets Transform lives. Washington DC.

IMF. (2015). How Does the IMF Encourage Greater Fiscal Transparency?

Interview. (December 12, 2011). Naveed Bakhshi, Former Afghanisan's Finance Ministry's Budget Execution Manager.

Interview. (January 25, 2012). Muhibullah Rahimi, Macroeconomic and Fiscal Coordinator, Afghanistan Parliamentary Assistance Program (APAP).

Interview. (November 21, 2011). M. Said Niazi, Civil Society Activist.

Interviews by Author. (November 2011-April 2012). Kabul.

Ishihara, Y., Sisk, P., Fernando, D., \& Jensen, P. (May 2008). Afghanistan: Public Financial Management Performance Assesment, Executive Summary.

Islamic Republic of Afganistan. (2012). Development Cooperation Report.

Islamic Republic of Afghanistan. (2007). Afghanistan National Development Strategy

Progress Report 2006/07. ANDS Secretariat.

Islamic Republic of Afghanistan. (2010). Development Cooperation Report. Kabul: Ministry of Finance.

Islamic Republic of Afghanistan. (July 20, 2010). Communique, The Kabul Process, Afghanistan National Development Strategy Prioritization and Implementation Plan (Mid 2010-Mid 2013). Kabul: Ministry of Finance of Afghanistan.

Islamic Republic of Afghanistan. (June 2011). Public Financial Management (PFM) Roadmap: Nine Months Status Report. Kabul: Ministry of Finance.

Ismalic Republic of Afghanistan. 1390 (2010/11) Citizens Budget. Ministry of Finance Retrieved from

http://www.budgetmof.gov.af/NationalBudget/1390Guideline/final_citizens\%20budget_englis h_may\%202011.pdf.

Lockhart, C. (2007). The Aid Relationship in Afghanistan: Struggling for Government Leadership. Global Economic Governance Programme's Working Paper 27, University of Oxford, Oxford.

Mikesell, J. (2013). Fiscal Administration. Boston: Cengage Learning.

Ministry of Finance of Afghanistan. (July 26, 2011). Press Release (Clarification of the Special Inspector General for Afghanistan Reconstruction [SIGAR] Report). Media Department.

OECD. (2015). States of Fragility 2015: Meeting Post-2015 Ambitions. Paris: OECD Publishing. 
Interview. (December 18, 2011). Osmani, S. A. Member of the Lower House Committee on Financial and Budget Affairs.

Renzio, P. d., \& Angemi, D. (2011). Comrades or Culprits? Donor Engagement and Budget Transparency in Aid Dependent Countries. IBEI Working Papers 2011/33, (Institute Barcelona D'Estudid Internationals). Retrieved from http://www.internationalbudget.org/wpcontent/uploads/Donor-Engagement-and-Budget-Transparency.pdf

Riā'sat-i 'Aumumī Aidārah-i Aumūr Va Dār al-ainshā-yi Shorā-yi Vazirān (Office of Administrative Affairs and Cabinet Secretariat). (1388 Solar Hijra Calender [2009]). Dast Āward'hā-yi Ūmda-yi Hukūmat Dar Haft Sāli Guzashta Wa Barnāmah'hā-yi Panj Sāli Āinda (the last Seven Years Government Achievments and the Next Five Years Programms). Kabul: Aidārah-'i Aumūr Va Arziābay.

SIGAR. Mission, Vision and Core Values. Retrieved from http://www.sigar.mil/about/mission.html

Stewart, F., \& Brown, G. (2010). Fragile States: Centre for Research on Inequality,Human Security and Ethnicity.

Surhke, A. (2011). When More is Less: The International Project in Afghanistan. London: Hurst and Company.

Synergy International Systems. (2015). National Budget and Aid Management Systems: DAD Afghanistan.

The Danish Institute for Human Rights. (December 3, 2014). New Afghan Law Grants Access to Information. Retrieved from http://www.humanrights.dk/news/new-afghan-lawgrants-access-information

The International Budget Project. (2006). Open Budget Initiative: More Public Information Needed to Hold Governments to Account.

The World Bank. (2014). The Worldwide Governance Indicators. Retrieved from http://info.worldbank.org/governance/wgi/index.aspx\#reports.

Torabi, Y., Director of Integrity Watch Afghanistan. (November 8, 2011). Interview by Author. Transitional Government of Afghanistan. (October 2004). Financial Report, 4th Quarter 1380-2nd Quarter 1383 (21 January 2001-20 September 2004). Ministry of Finance.

U.S. Government Accountability Office. (2009). Afghanistan's Security Environment. Washington.

Welsh, J., \& Woods, N. (Eds.). (2007). Temptations and Challenges in Canada's Aid Program: $\mathrm{CIGI}$ and Wilfrid Laurier University Press.

World Bank. World Development Indicators. Retrieved from http://data.worldbank.org/datacatalog/world-development-indicators. Retrieved April 17, 2014 http://data.worldbank.org/data-catalog/world-development-indicators

World Bank. (July 16, 2011). Issues and Challenges for Economic Growth and Sustainability in Afghanistan After 2014. 


\section{Working Papers}

The following GEG Working Papers can be downloaded at www.globaleconomicgovernance.org/working-papers

\begin{tabular}{|c|c|}
\hline Nematullah Bizhan & Improving the Fragile States' Budget Transparency: Lessons from Afghanistan \\
\hline Taylor St John and Noel Johnston & Who Needs Rules? Explaining Participation in the Investment Regime \\
\hline Zainab Usman & $\begin{array}{l}\text { The Successes and Failures of Economic Reform in Nigeria's Post-Military Political } \\
\text { Settlement }\end{array}$ \\
\hline Ivaylo laydjiev & $\begin{array}{l}\text { Host's Dilemma in International Political Economy: } \\
\text { The Regulation of Cross-Border Banking in Emerging Europe, 2004-2010 }\end{array}$ \\
\hline Carolyn Deere Birkbeck & $\begin{array}{l}\text { From 'Trade and Environment' to the Green Economy: The WTO's Environmental } \\
\text { Record and Discourse on Sustainable Development at } 20\end{array}$ \\
\hline Lauge Poulsen and Emma Aisbett & Diplomats Want Treaties: Diplomatic Agendas and Perks in the Investment Regime \\
\hline $\begin{array}{l}\text { Carolyn Deere Birkbeck and } \\
\text { Kimberley Botwright }\end{array}$ & $\begin{array}{l}\text { Changing Demands on the Global Trade and Investment Architecture: Mapping an } \\
\text { Evolving Ecosystem }\end{array}$ \\
\hline Pichamon Yeophantong & Civil Regulation and Chinese Resource Investment in Myanmar and Vietnam \\
\hline Nematullah Bizhan & $\begin{array}{l}\text { WP 2015/109 Continuity, Aid and Revival: State Building in South Korea, Taiwan, Iraq } \\
\text { and Afghanistan }\end{array}$ \\
\hline Camila Villard Duran & $\begin{array}{l}\text { WP 2015/108 The International Lender of Last Resort for Emerging Countries: A } \\
\text { Bilateral Currency Swap? }\end{array}$ \\
\hline Tu Anh Vu Thanh & $\begin{array}{l}\text { WP 2015/107 The Political Economy of Industrial Development in Vietnam: Impact of } \\
\text { State-Business Relationship on Industrial Performance 1986-2012 (forthcoming) }\end{array}$ \\
\hline Nilima Gulrajani & $\begin{array}{l}\text { WP 2015/106 Bilateral donors in the 'Beyond Aid' Agenda: The Importance of } \\
\text { Institutional Autonomy for Donor Effectiveness (forthcoming) }\end{array}$ \\
\hline Carolyn Deere Birkbeck & $\begin{array}{l}\text { WP 2015/105 WIPO's Development Agenda and Assistance to Developing Countries } \\
\text { (2004-2014): What Stymied Progress and Enduring Challenges }\end{array}$ \\
\hline Alexandra Olivia Zeitz & $\begin{array}{l}\text { WP 2015/104 A New Politics of Aid? The Changing International Political Economy of } \\
\text { Development Assistance: The Ghanaian Case }\end{array}$ \\
\hline Akachi Odoemene & $\begin{array}{l}\text { WP 2015/103 Socio-Political Economy and Dynamics of Government-Driven Land } \\
\text { Grabbing in Nigeria since } 2000\end{array}$ \\
\hline $\begin{array}{l}\text { David Ramos, Javier Solana, Ross P. } \\
\text { Buckley and Jonathan Greenacre }\end{array}$ & $\begin{array}{l}\text { WP 2015/102 Protecting the Funds of Mobile Money Customers in Civil Law } \\
\text { Jurisdictions }\end{array}$ \\
\hline Lise Johnson & $\begin{array}{l}\text { WP 2015/101 Ripe for Refinement: The State's Role in Interpretation of FET, MFN, } \\
\text { and Shareholder Rights }\end{array}$ \\
\hline Mthuli Ncube & WP 2015/100 Can dreams come true? Eliminating extreme poverty in Africa by 2030 \\
\hline Jure Jeric & $\begin{array}{l}\text { WP 2015/99 Managing risks, preventing crises - a political economy account of Basel } \\
\text { III financial regulations }\end{array}$ \\
\hline Anar Ahmadov & $\begin{array}{l}\text { WP 2014/98 Blocking the Pathway Out of the Resource Curse: What Hinders } \\
\text { Diversification in Resource-Rich Developing Countries? }\end{array}$ \\
\hline Mohammad Mossallam & WP 2015/97 Process matters: South Africa's Experience Exiting its BITs \\
\hline Geoffrey Gertz & $\begin{array}{l}\text { WP 2015/96 Understanding the Interplay of Diplomatic, Insurance and Legal } \\
\text { Approaches for Protecting FDI }\end{array}$ \\
\hline Emily Jones & $\begin{array}{l}\text { WP 2014/95 When Do 'Weak' States Win? A History of African, Caribbean and Pacific } \\
\text { Countries Manoeuvring in Trade Negotiations with Europe }\end{array}$ \\
\hline Taylor St John & WP 2014/94 The Origins of Advance Consent \\
\hline Carolyn Deere Birkbeck & $\begin{array}{l}\text { WP 2014/93 The Governance of the World Intellectual Property Organization: A } \\
\text { Reference Guide }\end{array}$ \\
\hline Tu Anh Vu Thanh & $\begin{array}{l}\text { WP 2014/92 WTO Accession and the Political Economy of State-Owned Enterprise } \\
\text { Reform in Vietnam }\end{array}$ \\
\hline Emily Jones & $\begin{array}{l}\text { WP 2014/91 Global Banking Standards and Low Income Countries: Helping or } \\
\text { Hindering Effective Regulation? }\end{array}$ \\
\hline Ranjit Lall & $\begin{array}{l}\text { WP 2014/90 The Distributional Consequences of International Finance: An Analysis of } \\
\text { Regulatory Influence }\end{array}$ \\
\hline Ngaire Woods & WP 2014/89 Global Economic Governance after the 2008 Crisis \\
\hline
\end{tabular}




\begin{tabular}{|c|c|}
\hline Folashadé Soule-Kohndou & $\begin{array}{l}\text { WP 2013/88 The India-Brazil-South Africa Forum - A Decade On: Mismatched } \\
\text { Partners or the Rise of the South? }\end{array}$ \\
\hline Nilima Gulrajani & WP 2013/87 An Analytical Framework for Improving Aid Effectiveness Policies \\
\hline Rahul Prabhakar & $\begin{array}{l}\text { WP 2013/86 Varieties of Regulation: How States Pursue and Set International } \\
\text { Financial Standards }\end{array}$ \\
\hline Alexander Kupatadze & $\begin{array}{l}\text { WP 2013/85 Moving away from corrupt equilibrium: 'big bang' push factors and } \\
\text { progress maintenance }\end{array}$ \\
\hline George Gray Molina & WP 2013/84 Global Governance Exit: A Bolivian Case Study \\
\hline Steven L. Schwarcz & $\begin{array}{l}\text { WP 2013/83 Shadow Banking, Financial Risk, and Regulation in China and Other } \\
\text { Developing Countries }\end{array}$ \\
\hline Pichamon Yeophantong & $\begin{array}{l}\text { WP 2013/82 China, Corporate Responsibility and the Contentious Politics of } \\
\text { Hydropower Development: transnational activism in the Mekong region? }\end{array}$ \\
\hline Pichamon Yeophantong & $\begin{array}{l}\text { WP 2013/81 China and the Politics of Hydropower Development: governing water and } \\
\text { contesting responsibilities in the Mekong River Basin }\end{array}$ \\
\hline Rachael Burke and Devi Sridhar & $\begin{array}{l}\text { WP } 2013 / 80 \text { Health financing in Ghana, South Africa and Nigeria: Are they meeting } \\
\text { the Abuja target? }\end{array}$ \\
\hline Dima Noggo Sarbo & $\begin{array}{l}\text { WP 2013/79 The Ethiopia-Eritrea Conflict: Domestic and Regional Ramifications and } \\
\text { the Role of the International Community }\end{array}$ \\
\hline Dima Noggo Sarbo & $\begin{array}{l}\text { WP 2013/78 Reconceptualizing Regional Integration in Africa: The European Model } \\
\text { and Africa's Priorities }\end{array}$ \\
\hline Abdourahmane Idrissa & WP 2013/77 Divided Commitment: UEMOA, the Franc Zone, and ECOWAS \\
\hline Abdourahmane Idrissa & WP 2013/76 Out of the Penkelemes: The ECOWAS Project as Transformation \\
\hline Pooja Sharma & WP 2013/75 Role of Rules and Relations in Global Trade Governance \\
\hline Le Thanh Forsberg & WP 2013/74 The Political Economy of Health Care Commercialization in Vietnam \\
\hline Hongsheng Ren & $\begin{array}{l}\text { WP 2013/73 Enterprise Hegemony and Embedded Hierarchy Network: The Political } \\
\text { Economy and Process of Global Compact Governance in China }\end{array}$ \\
\hline Devi Sridhar and Ngaire Woods & WP2013/72 'Trojan Multilateralism: Global Cooperation in Health' \\
\hline Valéria Guimarães de Lima e Silva & $\begin{array}{l}\text { WP2012/71 'International Regime Complexity and Enhanced Enforcement of } \\
\text { Intellectual Property Rights: The Use of Networks at the Multilateral Level' }\end{array}$ \\
\hline Ousseni llly & WP2012/70 'Trade Remedies in Africa: Experience, Challenges and Prospects' \\
\hline $\begin{array}{l}\text { Carolyn Deere Birckbeck and Emily } \\
\text { Jones }\end{array}$ & $\begin{array}{l}\text { WP2012/69 'Beyond the Eighth Ministerial Conference of the WTO: A Forward } \\
\text { Looking Agenda for Development' }\end{array}$ \\
\hline Devi Sridhar and Kate Smolina & $\begin{array}{l}\text { WP2012/68' Motives behind national and regional approaches to health and foreign } \\
\text { policy' }\end{array}$ \\
\hline Omobolaji Olarinmoye & $\begin{array}{l}\text { WP2011/67 'Accountability in Faith-Based Organizations in Nigeria: Preliminary } \\
\text { Explorations' }\end{array}$ \\
\hline Ngaire Woods & WP2011/66 'Rethinking Aid Coordination' \\
\hline Paolo de Renzio & $\begin{array}{l}\text { WP2011/65 'Buying Better Governance: The Political Economy of Budget Reforms in } \\
\text { Aid-Dependent Countries' }\end{array}$ \\
\hline Carolyn Deere Birckbeck & $\begin{array}{l}\text { WP2011/64 'Development-oriented Perspectives on Global Trade Governance: A } \\
\text { Summary of Proposals for Making Global Trade Governance Work for Development' }\end{array}$ \\
\hline $\begin{array}{l}\text { Carolyn Deere Birckbeck and Meg } \\
\text { Harbourd }\end{array}$ & $\begin{array}{l}\text { WP2011/63 'Developing Country Coalitions in the WTO: Strategies for Improving the } \\
\text { Influence of the WTO's Weakest and Poorest Members' }\end{array}$ \\
\hline Leany Lemos & $\begin{array}{l}\text { WP } 2011 / 62 \text { 'Determinants of Oversight in a Reactive Legislature: The Case of Brazil, } \\
1988-2005 \text { ' }\end{array}$ \\
\hline Valéria Guimarães de Lima e Silva & WP 2011/61 'Sham Litigation in the Pharmaceutical Sector'. \\
\hline Michele de Nevers & $\begin{array}{l}\text { WP 2011/60 'Climate Finance - Mobilizing Private Investment to Transform } \\
\text { Development.' }\end{array}$ \\
\hline Ngaire Woods & WP 2010/59 ' The G20 Leaders and Global Governance’ \\
\hline Leany Lemos & WP 2010/58 'Brazilian Congress and Foreign Affairs: Abdication or Delegation?' \\
\hline Leany Lemos \& Rosara Jospeh & $\begin{array}{l}\text { WP 2010/57 'Parliamentarians' Expenses Recent Reforms: a briefing on Australia, } \\
\text { Canada, United Kingdom and Brazil' }\end{array}$ \\
\hline Nilima Gulrajani & $\begin{array}{l}\text { WP } 2010 / 56 \text { 'Challenging Global Accountability: The Intersection of Contracts and } \\
\text { Culture in the World Bank' }\end{array}$ \\
\hline Devi Sridhar \& Eduardo Gómez & $\begin{array}{l}\text { WP 2009/55 'Comparative Assessment of Health Financing in Brazil, Russia and } \\
\text { India: Unpacking Budgetary Allocations in Health' }\end{array}$ \\
\hline
\end{tabular}




\begin{tabular}{|c|c|}
\hline Ngaire Woods & $\begin{array}{l}\text { WP 2009/54 'Global Governance after the Financial Crisis: A new multilateralism or } \\
\text { the last gasp of the great powers? }\end{array}$ \\
\hline Arunabha Ghosh and Kevin Watkins & $\begin{array}{l}\text { WP 2009/53 'Avoiding dangerous climate change - why financing for technology } \\
\text { transfer matters' }\end{array}$ \\
\hline Ranjit Lall & WP 2009/52 'Why Basel II Failed and Why Any Basel III is Doomed' \\
\hline Arunabha Ghosh and Ngaire Woods & WP 2009/51 'Governing Climate Change: Lessons from other Governance Regimes' \\
\hline Carolyn Deere - Birkbeck & $\begin{array}{l}\text { WP 2009/50 'Reinvigorating Debate on WTO Reform: The Contours of a Functional } \\
\text { and Normative Approach to Analyzing the WTO System' }\end{array}$ \\
\hline Matthew Stilwell & $\begin{array}{l}\text { WP 2009/49 'Improving Institutional Coherence: Managing Interplay Between Trade } \\
\text { and Climate Change' }\end{array}$ \\
\hline Carolyn Deere & $\begin{array}{l}\text { WP 2009/48 'La mise en application de l'Accord sur les ADPIC en Afrique } \\
\text { francophone' }\end{array}$ \\
\hline Hunter Nottage & WP 2009/47 'Developing Countries in the WTO Dispute Settlement System' \\
\hline Ngaire Woods & $\begin{array}{l}\text { WP 2008/46 'Governing the Global Economy: Strengthening Multilateral Institutions' } \\
\text { (Chinese version) }\end{array}$ \\
\hline Nilima Gulrajani & $\begin{array}{l}\text { WP 2008/45 'Making Global Accountability Street-Smart: Re-conceptualizing } \\
\text { Dilemmas and Explaining Dynamics' }\end{array}$ \\
\hline Alexander Betts & WP 2008/44 'International Cooperation in the Global Refugee Regime' \\
\hline Alexander Betts & WP 2008/43 'Global Migration Governance’ \\
\hline Alastair Fraser and Lindsay Whitfield & WP 2008/42 'The Politics of Aid: African Strategies for Dealing with Donors' \\
\hline Isaline Bergamaschi & WP 2008/41 'Mali: Patterns and Limits of Donor-Driven Ownership' \\
\hline Arunabha Ghosh & $\begin{array}{l}\text { WP 2008/40 'Information Gaps, Information Systems, and the WTO's Trade Policy } \\
\text { Review Mechanism' }\end{array}$ \\
\hline Devi Sridhar and Rajaie Batniji & $\begin{array}{l}\text { WP 2008/39 'Misfinancing Global Health: The Case for Transparency in } \\
\text { Disbursements and Decision-Making' }\end{array}$ \\
\hline $\begin{array}{l}\text { W. Max Corden, Brett House and } \\
\text { David Vines }\end{array}$ & $\begin{array}{l}\text { WP 2008/38 'The International Monetary Fund: Retrospect and Prospect in a Time of } \\
\text { Reform' }\end{array}$ \\
\hline Domenico Lombardi & WP 2008/37 'The Corporate Governance of the World Bank Group' \\
\hline Ngaire Woods & WP 2007/36 'The Shifting Politics of Foreign Aid' \\
\hline Devi Sridhar and Rajaie Batniji & $\begin{array}{l}\text { WP 2007/35 'Misfinancing Global Health: The Case for Transparency in } \\
\text { Disbursements and Decision-Making' }\end{array}$ \\
\hline Louis W. Pauly & $\begin{array}{l}\text { WP 2007/34 'Political Authority and Global Finance: Crisis Prevention in Europe and } \\
\text { Beyond' }\end{array}$ \\
\hline Mayur Patel & $\begin{array}{l}\text { WP } 2007 / 33 \text { 'New Faces in the Green Room: Developing Country Coalitions and } \\
\text { Decision Making in the WTO' }\end{array}$ \\
\hline Lindsay Whitfield and Emily Jones & $\begin{array}{l}\text { WP } 2007 / 32 \text { 'Ghana: Economic Policymaking and the Politics of Aid Dependence' } \\
\text { (revised October 2007) }\end{array}$ \\
\hline Isaline Bergamaschi & WP 2007/31 'Mali: Patterns and Limits of Donor-driven Ownership' \\
\hline Alastair Fraser & WP 2007/30 'Zambia: Back to the Future?' \\
\hline Graham Harrison and Sarah Mulley & WP 2007/29 'Tanzania: A Genuine Case of Recipient Leadership in the Aid System?' \\
\hline Xavier Furtado and W. James Smith & WP 2007/28 ‘Ethiopia: Aid, Ownership, and Sovereignty’ \\
\hline Clare Lockhart & $\begin{array}{l}\text { WP 2007/27 'The Aid Relationship in Afghanistan: Struggling for Government } \\
\text { Leadership' }\end{array}$ \\
\hline Rachel Hayman & WP 2007/26 '“Milking the Cow”: Negotiating Ownership of Aid and Policy in Rwanda' \\
\hline Paolo de Renzio and Joseph Hanlon & $\begin{array}{l}\text { WP } 2007 / 25 \text { 'Contested Sovereignty in Mozambique: The Dilemmas of Aid } \\
\text { Dependence' }\end{array}$ \\
\hline Lindsay Whitfield & WP 2006/24 'Aid's Political Consequences: the Embedded Aid System in Ghana' \\
\hline Alastair Fraser & WP 2006/23 'Aid-Recipient Sovereignty in Global Governance' \\
\hline David Williams & WP 2006/22 “'Ownership,” Sovereignty and Global Governance' \\
\hline Paolo de Renzio and Sarah Mulley & $\begin{array}{l}\text { WP } 2006 / 21 \text { 'Donor Coordination and Good Governance: Donor-led and Recipient-led } \\
\text { Approaches' }\end{array}$ \\
\hline $\begin{array}{l}\text { Andrew Eggers, Ann Florini, and } \\
\text { Ngaire Woods }\end{array}$ & WP 2005/20 'Democratizing the IMF' \\
\hline
\end{tabular}




\begin{tabular}{|c|c|}
\hline Ngaire Woods and Research Team & $\begin{array}{l}\text { WP 2005/19 'Reconciling Effective Aid and Global Security: Implications for the } \\
\text { Emerging International Development Architecture' }\end{array}$ \\
\hline Sue Unsworth & WP 2005/18 'Focusing Aid on Good Governance' \\
\hline $\begin{array}{l}\text { Ngaire Woods and Domenico } \\
\text { Lombardi }\end{array}$ & WP 2005/17 'Effective Representation and the Role of Coalitions Within the IMF' \\
\hline Dara O’Rourke & $\begin{array}{l}\text { WP 2005/16 'Locally Accountable Good Governance: Strengthening Non- } \\
\text { Governmental Systems of Labour Regulation'. }\end{array}$ \\
\hline John Braithwaite & WP 2005/15 'Responsive Regulation and Developing Economics'. \\
\hline David Graham and Ngaire Woods & WP 2005/14 'Making Corporate Self-Regulation Effective in Developing Countries'. \\
\hline Sandra Polaski & $\begin{array}{l}\text { WP 2004/13 'Combining Global and Local Force: The Case of Labour Rights in } \\
\text { Cambodia' }\end{array}$ \\
\hline Michael Lenox & $\begin{array}{l}\text { WP 2004/12 'The Prospects for Industry Self-Regulation of Environmental } \\
\text { Externalities' }\end{array}$ \\
\hline Robert Repetto & WP 2004/11 'Protecting Investors and the Environment through Financial Disclosure' \\
\hline Bronwen Morgan & WP 2004/10 'Global Business, Local Constraints: The Case of Water in South Africa' \\
\hline Andrew Walker & $\begin{array}{l}\text { WP 2004/09 'When do Governments Implement Voluntary Codes and Standards? The } \\
\text { Experience of Financial Standards and Codes in East Asia' }\end{array}$ \\
\hline Jomo K.S. & WP 2004/08 'Malaysia's Pathway through Financial Crisis' \\
\hline Cyrus Rustomjee & WP 2004/07 'South Africa's Pathway through Financial Crisis' \\
\hline Arunabha Ghosh & WP 2004/06 'India's Pathway through Financial Crisis' \\
\hline Calum Miller & WP 2004/05 'Turkey’s Pathway through Financial Crisis' \\
\hline $\begin{array}{l}\text { Alexander Zaslavsky and Ngaire } \\
\text { Woods }\end{array}$ & WP 2004/04 'Russia's Pathway through Financial Crisis' \\
\hline Leonardo Martinez-Diaz & WP 2004/03 'Indonesia's Pathway through Financial Crisis' \\
\hline Brad Setser and Anna Gelpern & WP 2004/02 'Argentina's Pathway through Financial Crisis' \\
\hline Ngair & 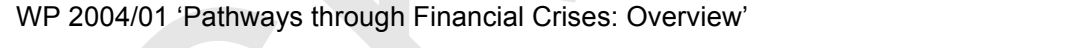 \\
\hline
\end{tabular}


The Global Economic Governance Programme was established in 2003 to foster research and debate into how global markets and institutions can better serve the needs of people in developing countries. The program is co-hosted by University College and the Blavatnik School of Government.

The three core objectives of the Programme are:

$\diamond$ to conduct and foster research into international organizations and markets as well as new publicprivate governance regimes

$\diamond$ to create and develop a network of scholars and policy-makers working on these issues

$\diamond$ to influence debate and policy in both the public and the private sector in developed and developing countries
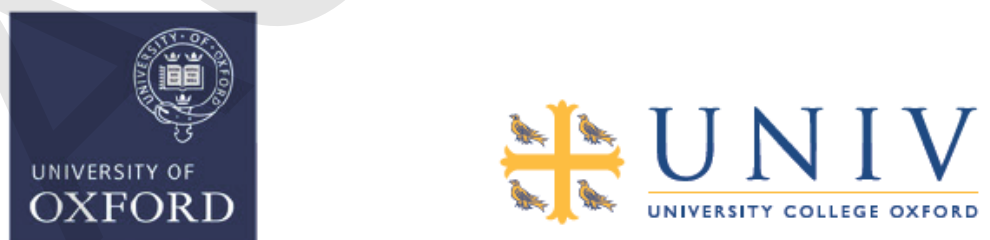